\title{
The Rise and Fall of Small Business Enterprises
}

\author{
Falih M. Alsaaty ${ }^{1}$, Hany H. Makhlouf ${ }^{2}$ \\ ${ }^{1}$ College of Business, Bowie State University, Bowie, Maryland, USA \\ ${ }^{2}$ School of Business and Public Administration, University of the District of Columbia, Washington DC, USA \\ Email: FAlsaaty@Bowiestate.edu, hanyhmakhlouf@gmail.com
}

How to cite this paper: Alsaaty, F. M., \& Makhlouf, H. H. (2020). The Rise and Fall of Small Business Enterprises. Open Journal of Business and Management, 8, 1908-1916. https://doi.org/10.4236/ojbm.2020.84116

Received: June 4, 2020

Accepted: July 28, 2020

Published: July 31, 2020

Copyright (C) 2020 by author(s) and Scientific Research Publishing Inc. This work is licensed under the Creative Commons Attribution International License (CC BY 4.0).

http://creativecommons.org/licenses/by/4.0/

Open Access

\begin{abstract}
Small business is universally recognized as the engine of the world economy. It is praised for adding substantially to every country's gross domestic product (GDP), employment, innovative ability, and tax base. However, the survival rate of small businesses in their first ten years of operation is not high. Only about 20 percent of new business enterprises survive beyond their first ten years. Of those few are referred to as gazelles because they grow fast into medium and large corporations, but many prefer to remain small. This study, which is written to students and potential entrepreneurs, explores the strengths and weaknesses of small business enterprises and the factors that contribute to their success or failure. Hopefully, it would contribute to the literature in the fields of entrepreneurship and small business administration.
\end{abstract}

\section{Keywords}

Small Business, Affordable Loss, Growth-Stability Strategies, Meaning of Failure

\section{Introduction}

Collectively and from an economic standpoint, small businesses are not small. Historically and today, the small business sector is responsible for a significant portion of all countries' GPD, private sector employment, and economic vitality. A 2016 study by the World Entrepreneurship Center/Index revealed that small businesses could be responsible for as much as 84 percent of the world's GDP (Mason, 2020). A study by Mason (2020) further estimates that 100 million small businesses are established around the world every year. According to the World Bank (n.d.), those small enterprises are responsible for creating seven out of every ten jobs in the emerging economies. Similarly, they are responsible for the creation of most jobs in the advanced economies. Yet, a large number of small businesses don't survive beyond their first five years, and most of them don't 
survive beyond their first ten years.

For example, the Center for Economic Development of the University of Alaska (2020) reports that "in Alaska, 27 percent of new businesses (which are usually small) fail during their first year, 35 percent during the first two years, 47 percent during the first three years, ... and 52 percent during the first five years". The Small Business Administration (SBA) also indicates that only "about one in three small businesses get to the ten-year mark" (Otar, 2018). This is not untypical in comparison to many other countries. This study examines the causes and consequences of small business failure, hence its value to potential entrepreneurs and students of small business administration.

\section{Confusing Definitions of Small Businesses}

There is not a standard definition of small businesses that is universally accepted. Scholars, business groups, and governmental organizations differ in their definitions. There are differences even among government agencies in the same countries. Hence, there is a great deal of confusion in determining the characteristics of small businesses.

To the government of Australia, for example, a business enterprise is to be considered small if it has 20 paid employees or less. The Canadian government, on the other hand, classifies businesses as small if they have less than $100 \mathrm{em}$ ployees. The British government considers a business to be small if it has an annual revenue that does not exceed $\$ 6.5$ million and employs less than 50 workers. In the United States, the Small Business Administration (SBA) classifies small businesses on the basis of their revenues and business lines/industries, as Table 1 indicates. However, periodic changes in the maximum revenues are made as the cost of living changes.

\section{Contributions of Small Business}

The universal interest in job creation and technological innovations usually puts

Table 1. Summary of SBA's small business definition by industry.

\begin{tabular}{|c|c|}
\hline Line of Business & Average Maximum Level \\
\hline Agriculture & Annual income less than $\$ 750,000$ \\
\hline Mining & 1500 workers \\
\hline Construction & Annual income of $\$ 36.5$ million \\
\hline Manufacturing & 1500 workers \\
\hline Wholesaling and transportation & 250 workers \\
\hline Retailing & Annual revenue of $\$ 7.5$ million \\
\hline Financial services & $\$ 38.5$ million in annual revenue and 1500 employees \\
\hline Insurance & $\$ 38.5$ million in annual revenue and 1500 employees \\
\hline Health services & $\$ 38.5$ million in annual revenue \\
\hline
\end{tabular}

Source: SBA and Mcintyre, 2020. 
these contributions on top of the list of small business contributions to the economy. These are also main reasons why political leaders are eager to support taxpayer-financed programs in support of small business creation and sustainability. According to the U.S. Small Business Administration (SBA), whose mission is to extend technical and financial benefits to entrepreneurs and the small business sector in general, small businesses add about 1.8 million net jobs annually to the U.S. economy, and account for $47.3 \%$ of private sector jobs in the nation (2019 Small Business Profiles). A study by the Congressional Research Service (2019) also indicates that the gross job creation in the United States by small business in the years following the Great Recession of 2008-2009 ranged from over 8.5 million jobs in 2011 to over 9.2 million in 2018 (Table 2).

As Leebaert (2006) observes, "small businesses produce 13 to 14 times more patents per employee than do large firms". Leebaert (2006) also notes that "small business patents are twice as likely as those from the larger firms to be among the ... most cited (patents)".

Other major benefits of small business include:

1) Contributing significantly to the GDP and constituting a major part of GDP growth.

2) Expanding the tax base.

3) Satisfying a need in the marketplace, thus, improving the quality of life.

4) Filling gaps in the production of needed goods and services that are ignored by large corporations.

5) Adding vigor to economically depressed regions.

6) Raising the social and financial standing of business creators (entrepreneurs).

7) Raising efficiency in the marketplace by increasing competition.

8) Improving and customizing customer service.

9) Increasing exports.

\section{Small Business Strengths and Weaknesses}

Table 3 indicates that not all is well with small business establishments. Like

Table 2. Gross job creation by small business in the united states.

\begin{tabular}{cc}
\hline Year & Small Business Gross Job Creation \\
\hline 2011 & $8,537,881$ jobs \\
2012 & $8,976,857$ \\
2013 & $8,777,814$ \\
2014 & $8,945,569$ \\
2015 & $8,227,262$ \\
2016 & $9,362,714$ \\
2017 & $9,257,984$ \\
2018 & $9,273,737$ \\
\hline
\end{tabular}

Source: Based on Congressional Research Service, 2019. 
Table 3. Strengths and weaknesses of small business enterprises.

\begin{tabular}{ll}
\hline \multicolumn{1}{c}{ Strengths } & \multicolumn{1}{c}{ Weaknesses } \\
\hline $\begin{array}{l}\text { Ability to react fast to external challenges } \\
\text { Flexibility and capacity to make fast change in } \\
\text { direction }\end{array}$ & Inability to attract highly experienced managers \\
Willingness to customize products and services & Low employee-pay and benefits \\
Informality in relationships & Difficulty in raising capital \\
Short lines of communication & Low access to credit \\
Ability to make fast decisions & Limited capacity to diversify product lines \\
Easy to establish and control &
\end{tabular}

Source: The Authors.

large and medium-size businesses, they have their strengths and their weaknesses that impact their survival and profitability. For individual businesses, however, their strong points have to outweigh their weak point if they manage to survive in today's dynamic business environment.

\section{The Growth or Decline Myth}

It is often stated that if a business does not grow it would decline. This is more of a myth than a reality. Most business enterprises start small but do not grow, or they grow slightly over a long period of time. Some prefer not to grow. On the other hand, some small businesses prematurely follow growth strategies despite their limited resources and inadequate management experience. Such strategies often hasten their decline and possible death. As Horn and Pleasance (2012) of McKinsey \& Company indicate on the basis of their small business consulting experience, "not all owners of small businesses want them to grow". Collins (2009) in his book entitled "how the Mighty Fall" and Casto (2009) in his "the Five Stages of Decline" also indicate that "growth is not always a good thing for a business... When an organization grows beyond its ability to fill its key seats with the right people, it has set itself up for a fall".

\section{Do Small Firms Have a Life Cycle?}

As businesses face and adapt to internal and/or environmental changes, they enter new phases that reflect their levels of maturity, experience, resources, and capacity. Churchill and Lewis (1983) identify the following phases, through which some small businesses may pass over the long range:

Phase I: Setting the stage to become a workable business.

Phase II: Creating conditions needed for survival.

Phase III: Operating successfully and setting the stage for possible expansion.

Phase IV: Taking-off, and possible founders' disengagement to give more responsibility to appointed professionals/managers.

Phase V: Reaching maturity and further professionalization of operations, and 
possibility of further growth or decline.

Meanwhile, Collins (2009) identifies phases/stages of small business decline, which end up with the enterprise ceasing to remain as an independent entity under the control of the original owners/founders:

Phase I: Leaders become arrogant about prior achievements and "lose sight of the true underlying factors" behind those achievements (Collins, 2009).

Phase II: "Undisciplined leaps into areas" where the business in its current condition cannot be successful.

Phase III: Underestimating risk, that is "taking outsized risks and acting in a way that denies the consequences of those risks" (Collins, 2009).

Phase IV: Grasping for salvation, that is resorting to "a bold but untested strategy, a radical transformation, or other ... silver bullet solutions" (Collins, 2009).

Phase V: Capitulation to irrelevance or death.

\section{Affordable Loss Principle and Business Survival}

In venturing into new moderately risky and unfamiliar areas, managers of small businesses, sometimes, anticipate some limited or measured losses that their businesses can withstand for the short term. They do not see such losses as a major threat to the venture's long-term survival or sustainability. Ucbasaran et al. (2013) explain this "affordable loss principle" as having "decision makers estimating what they might be able to put at risk and determining what they are willing to lose to follow a course of action" which may have a good chance of success over the long range. If the affordable loss limit or threshold is reached, the business may abandon that distant objective, thus avoiding more costly and undesirable future outcomes. Therefore, applying the "affordable loss principle" carefully, under certain conditions and for some major long-term gain, may not signify business failure in the traditional sense.

\section{Forty Causes of Small Business Failure}

There are many reasons behind the failure/death of small business enterprises. Many of them are often put under the big umbrella of "poor management". Following are 40 of the most recognized causes:
1) Profit erosion
2) Undercapitalization
3) Lack of cash cushion
4) Lack of marketing focus
5) Outdated and low-quality product
6) Poor customer relations
7) Bad pricing strategy
8) Premature/uncontrolled growth
9) Ineffective leadership
10) Inability to control expenses 
11) High overhead cost

12) Overlooking details

13) Wrong reaction to new external and/or internal challenges

14) Fraud and legal disputes

15) Failure to plan

16) Getting outsmarted by competitors

17) Overdependence on one or few customers

18) Leadership conflict/rivalry/power struggle

19) Low product acceptance

20) Failure to deliver value

21) Poor inventory management

22) Lack of product differentiation

23) Macro-economic challenges left unanswered

24) Excessive government regulations

25) Failure to learn from mistakes

26) Rigid and unproductive organization culture

27) Loss of experienced staff/managers

28) Excessive reliance on borrowed capital (high leverage)

29) Lack of vision

30) Failure to seek outside help for problem solving

31) Poor internal communication

32) Excessive concentration of authority

33) Overlapping responsibilities

34) Bad location

35) Technologically freezing in place for a long time and failure to take advantage of new technological advances

36) Sticking to ineffective competitive formula/strategy

37) Under-estimating or over-estimating risks in the marketplace

38) Failure to recognize and take advantage of new market opportunities

39) Negative cash flow

40) Loss of key suppliers

\section{Consequences of Small Business Failure}

Small business failure, which is often a management failure, can lead to one of the following outcomes:

1) Change in ownership and management as a result of the acquisition of the business by new owners or another more successful enterprise: However, this is not easy to do, if the failing business is highly leveraged. Excessive debt discourages potential buyers, who may believe that they can revive the failing business and run it better than its original (current) managers have done.

2) Seeking bankruptcy protection for the purpose of restructuring debt, re-organizing, and crafting a new turnaround strategy.

3) Declaring bankruptcy and liquidating the business. 
Failure of entrepreneurial ventures has financial, human, economic, and psychological costs. From a financial standpoint, the entrepreneur may lose more than the equity invested in the failing venture if the business is a single proprietorship or a partnership. The human cost would include having some or all of the employees lose their jobs, accrued benefits, and future incomes. In addition, they and the entrepreneurs would have their careers disrupted and their dreams destroyed. The economic cost includes the failing business ceasing to contribute to the nation's output of goods and services (GDP), employment, and government revenues by paying taxes.

The negative psychological impact of the venture's failure on the entrepreneur can be long-lasting. Some entrepreneurs recover from such a psychological blow faster than some others, particularly if they have had a record of success in establishing and running other ventures. Serial entrepreneurs may not remain emotionally attached to failing ventures for a long period of time, they can move on, and they tend to learn from their mistakes. As Dias and Teixeira (2017) point out, "successful business leaders are not born successful but rather fail continually until they achieve success".

Some entrepreneurs, on the other hand, lose the fire in their bellies and their self-confidence after their first ventures fail. One failure may cause them to withdraw from their business and social networks. Based on their studies of entrepreneurs whose first ventures have failed, Dias and Teixeira (2017) observe that some entrepreneurs feel stigmatized for the rest of their lives as a result of their failure to make their ventures a success. They end up changing their careers and avoiding future risky activities.

Dias and Teixeira (2017) also note that entrepreneurs, who have previously succeeded, or are not emotionally attached to a relatively new venture, would be more likely not to over-react psychologically due to a venture's failure. They further indicate that some may feel that their prior success was likely "due to the characteristics they possess, such as resilience (and) favorable personal background". Those entrepreneurs would engage in future ventures and "are prone to make sense of failure in a more beneficial way" (Dias \& Teixeira, 2017).

\section{Prerequisites for Small Business Success}

Katz and Green (2018) define small business success as the outcome of planning, and of timely and appropriate actions undertaken by the entrepreneur/owner. They point out that "those who plan and act are the ones who most often succeed". Following are twelve planning and action-related prerequisites for small business success:

1) Crafting a detailed and well-researched business plan to guide in future decisions and actions.

2) Having enough capital to ensure liquidity.

3) Maintaining good customer relations at all costs.

4) Avoiding freezing in place through innovations and periodic updating of 
policies and procedures.

5) Reacting appropriately to internal and external changes.

6) Building a team and encouraging a team spirit.

7) Instituting a good cost control system.

8) Knowing the competitors and adopting a good competitive strategy.

9) Instituting a good inventory management system.

10) Managers lead by example.

11) Instituting a cost-effective Management Information System to help in decision-making and control.

12) Choosing the right location.

\section{Conclusion}

The small business sector is one of the most important sectors in all countries, regardless of the size of their economies and their stage of development. It continues to grow year after year despite the increase in the size, number, and influence of large multinational corporations. Small business is also the largest generator of jobs and the most innovator.

The United States alone has over 30 million small businesses, which generate 44 percent of economic activities, according to Office of Advocacy of the Small Business Administration (SBA). Those businesses employed about 60 million workers, or 47.3 percent of the private workforce in 2016, and "added 1.8 net new jobs in the last year studied", according to the SBA. Reliance on small businesses for job generation is even greater in other industrialized countries like Italy and Spain as well as all of the emerging economies.

A major problem faced by small businesses, however, is their high death rate in the first ten years of operation. This is caused by many internal and external challenges, the most noted of which is their inability to attract and retain highly experienced manager, raise sufficient capital, and benefit from the economies of scale. This is why governments frequently institute special programs to provide small businesses with technical and financial assistance in order to improve their competitive standing in today's complex and dynamic world economy.

This study is limited to small businesses in their first ten years. Suggested future research should include the experiences of small businesses beyond their first ten years, particularly if they are family owned. Future research should also make a distinction between the experiences of manufacturing as opposed to service/retail establishments.

\section{Conflicts of Interest}

The authors declare no conflicts of interest regarding the publication of this paper.

\section{References}

Casto, J. (2009). The Five Stages of Decline. Capacity Magazine. Huntington, Virginia: Marshall University's Institute for Advanced Flexible Manufacturing. 
Churchill, N., \& Lewis, V. (1983). The Five Stages of Small Business Growth. Harvard Business Review, May Issue.

Collins, J. (2009). How the Mighty Fall. Boulder, Colorado: Random House Business.

Congressional Research Service (2019). Small Business Administration and Job Creation. https://crsreports.congress.gov

Dias, A., \& Teixeira, A. (2017). The Anatomy of Business Failure: A Qualitative Account of Its Implications for Future Business Success. European Journal of Management and Business Economics, 26, 2-20. https://doi.org/10.1108/EJMBE-07-2017-001

Horn, J., \& Pleasance, D. (2012). Restarting the U.S. Small Business Growth Engine. New York: McKinsey \& Co.

https://www.mckinsey.com/featured-insights/employment-and-growth/restarting-theus-small-business-growth-engine

Katz, J., \& Green, R. (2018). Entrepreneurial Small Business. New York: McGraw-Hill Book Company.

Leebaert, D. (2006). How Small Businesses Contribute to U.S. Economic Expansion. Economic Perspectives, 11, 2-26.

Mason, M. (2020). Research on Small Business. A Paper. http://www.moyak.com/papers/small-business-failure.html

Mcintyre, G. (2020). What Is the SBA's Definition of Small Business? https://www.fundera.com/blog/sba-definition-of-small-business https://fundera.com/blog/author/georgia

Otar, C. (2018). What Percentage of Small Businesses Fail, and How Can You Avoid Being One of Them. Forbes Finance Council. https://www.forbes.com/sites/forbesfinancecouncil/2018/10/25/what-percentage-of-sm all-businesses-fail-and-how-can-you-avoid-being-one-of-them/\#6

The World Bank (n.d.). Small and Medium Enterprises Finance. https://worldbank.org/en/topics/smefinance

Ucbasaran, D. et al. (2013). Life after Business Failure: The Process and Consequences of Business Failure for Entrepreneurs. Journal of Management, 39, 163-202.

http://www.sagepub.com/journals

https://doi.org/10.1177/0149206312457823 